\title{
不安定特性発生時の斜流ポンプ動翼内部流れの時間変化
}

\author{
萩谷 功*1, 加藤 千幸*2, 山出 吉伸*3, 深谷 征史 ${ }^{* 4}$, 長原 孝英*5
}

\section{Unsteady blade-passage flows of a mixed-flow pump at performance-curve instability}

\author{
Isao HAGIYA*1, Chisachi KATO*2, Yoshinobu YAMADE*3 ${ }^{* 3}$, Masashi FUKAYA*4 \\ and Takahide NAGAHARA ${ }^{* 5}$ \\ ${ }^{* 1, * 4}$ Hitachi, Ltd., Research and Development Group \\ 832-2 Horiguchi, Hitachinaka-shi, Ibaraki 312-0034, Japan \\ ${ }^{* 2}$ Institute of Industrial Science, The University of Tokyo \\ 4-6-1 Komaba, Meguro-ku, Tokyo 153-8505, Japan \\ ${ }^{* 3}$ Mizuho Information and Research Institute, Inc. \\ 2-3 Kanda Nishiki-cho, Chiyoda-ku, Tokyo 101-8443, Japan \\ ${ }^{* 5}$ Hitachi, Ltd., Industrial Products Company \\ 603 Kandatsu-machi, Tsuchiura-shi, Ibaraki 300-0013, Japan
}

Received: 23 August 2017; Revised: 8 November 2017; Accepted: 26 December 2017

\begin{abstract}
For designing a high-performance mixed-flow pump, control and suppression of performance-curve instability is crucial. For doing so, clarification of the essential flow physics that leads to the performance-curve instability is crucial in addition to an accurate prediction of the performance curve. We investigated internal flows of a mixed-flow pump, with performance-curve instability at round $60 \%$ of the designed flow rate, by using Large Eddy Simulation (LES). In the previous report, we clarified that drop of the Euler's head caused by stall near the tip of the impeller's blades is the major cause of the performance-curve instability. In the present report, we investigated in detail unsteady internal flows of individual blade passage near the head-drop point. As a result, we clarified the followings. (1) When the flow rate through a blade passage is low, the Euler's head is high for that particular passage, and this condition propagates in the direction of the impeller rotation for the whole impeller while the impeller makes approximately 20 revolutions. (2) Upstream flow of the stalled blade passage is deviated to the downward neighboring blade passage, resulting in increase in the load of the neighboring blade near its trailing edge. The neighboring blade passage will then be stalled. (3) When the flow rate in a stalled blade passage reaches the minimum, the passage starts to recover from stall while the pressure gradient in the streamwise direction will decrease.
\end{abstract}

Keywords : Mixed-flow pump, Performance curve instability, Stall, Unsteady passage flow, Large eddy simulation

\section{1. 緒}

ターボ機械の長年の課題として，機械の運転を不安定にする不安定特性（右上がり揚程特性）の抑制がある. ポンプについては，キャビテーション性能の向上，運転範囲の拡大に加えて，高効率化も重要であり，また，ポ ンプを接続する配管強度やケーシング強度の信頼性を向上させるために，締切揚程比の低減も課題である。これ ら要求を全て満足させようとすると, 不安定特性が発生しやすい.

不安定特性の抑制のためには，不安定特性が発生する詳細なメカニズムの解明が必要である。黒川ら（黒川他， 1993）は羽根車入口の再循環流モデルに基づいた性能予測法を提案し，不安定特性が発生する原因は，羽根車上 流に再循環流が形成され，動翼に流入する流れに与えられる強い予旋回の影響で理論揚程が急激に低下するため

\footnotetext{
No.17-00363 [DOI:10.1299/transjsme.17-00363], J-STAGE Advance Publication date : 12 January, 2018

*1 正員, (株) 日立製作所 研究開発グループ (テ312-0034 茨城県ひたちなか市堀口 832-2)

*2 正員, フェロー，東京大学 生産技術研究所（广153-8505 東京都目黒区駒場 4-6-1）

*3 正員，みずほ情報総研（株）（广101-8443＼cjkstart東京都千代田区神田錦町 2-3）

${ }^{* 4}$ 正員，フェロー，（株）日立製作所 研究開発グループ

*5 正員，(株)日立製作所 インダストリアルプロダクツ社（テ300-0013＼cjkstart茨城県土浦市神立町 603）

E-mail of corresponding author: isao.hagiya.un@hitachi.com
} 
だとしている. 後藤ら（Goto, 1992）は不安定特性が発生する際には，動翼の負圧面シュラウド側にはく離が発生 して低エネルギー流体が集積する兆候が見られ，不安定特性は動翼の失速により発生すると考察している. 西ら （西他, 2013）は動翼先端流れに注目し，壁面失速に起因した逆流が不安定特性の原因であると報告している．し かし，不安定特性が発生する流量付近の内部流れは三次元性と非定常性が強いため，この流量付近で流量の変化 に対する流れの変化を詳細に分析し，不安定特性が発生するメカニズムを説明した報告は未だない，さらに，一 般に動翼の失速タイプには前縁失速型，後縁失速型，および薄翼失速型などの種類があり，失速特性も異なる

（McCullough and Gault, 1951; Hirose, 2003）が，不安定特性が発生している場合の失速パターンも明らかにされて いない.このように, ポンプにおいて不安定特性発生のメカニズムは未だ完全には解明されておらず, そのため, 不安定特性を抑制した限界設計は実現されていない.

ポンプの不安定特性の解明のためには内部流れを詳細に把握する必要があるが，実験により内部流れを詳細に 把握することには限界があり，内部流れを精度良く予測できるシミュレーション技術の開発が望まれている．近 年の計算機性能の向上とシミュレーション技術の発達とに伴い, ポンプの設計にも Reynolds-Averaged

Navier-Stokes Simulation（RANS）の適用が普及している（Nagahara et al., 2006; Hiradate et al., 2010; Kobayashi et al., 2013）。しかし，不安定特性が発生する流量付近の内部流れは，大規模なはく離や局所的な失速を伴い，非定常性 が強くなるため, RANSによりこのような内部流れを高精度に予測することは難しい. 不安定特性発生時の内部 流れの解析には, 大規模なはく離を伴った, 非定常性が強い流れを高精度に予測できる Large Eddy Simulation (LES) の適用が有用である. 加藤ら（加藤他, 2002）や山出ら（Yamade et al., 2009）は不安定特性の現象解明を目的とし て，LES を用いた斜流ポンプの予測手法を検討し，不安定特性が発生して全揚程が局所的に低下する流量点にお いては，動翼のチップ側後縁の圧力が増加し，流れが逆流するといった特徵的な流れ場が観察されたことを報告 している. Paco 等（Paco et al., 2017）はポンプ運転時のポンプタービンにおいて，低負荷（低流量）条件におい てディフューザ流路で発生する旋回失速を比較的大規模な LES 解析により再現することに成功し, ディフューザ 流路内で失速セルが旋回するメカニズムを明らかにしている. しかしながら, 本研究が対象としているような比 較的比速度が高い斜流ポンプの羽根車動翼内の流れが，揚程が右上がり特性を示寸流量時にどのように時間変化

しているのかに関してはほとんど理解されていない.

本研究では, 60\%流量付近に不安定特性を有する比速度 $1000\left[\mathrm{~min}^{-1}, \mathrm{~m} 3 / \mathrm{min}, \mathrm{m}\right]$ の斜流ポンプの内部流れを LES により解析し，不安定特性の発生メカニズムを詳細に解明することを目的としている．前報（萩谷他, 2016）にお いては，揚程曲線の計算值が実測値と比較的良く一致し，解析手法が妥当であることを報告し，不安定特性発生 時には動翼チップ近傍領域が後縁側から発生した失速領域で覆われることを明らかにした。 その結果として, 動 翼前縁側において仕事がなされなくなり，理論揚程及び全揚程が低下して不安定特性が発生することを明らかに した．また，不安定特性が発生する過渡時の流量点においては，失速域で覆われた動翼翼間と覆われていない翼 間とが混在することを報告した，本論文では，不安定特性発生時の動翼内部の非定常流れを詳細に分析した結果 を報告する。

\section{2. 主な記号および略号}

$\begin{array}{lll}Q & \text { : 流量 } & {\left[\mathrm{m}^{3} / \mathrm{s}\right]} \\ Q_{\mathrm{BEP}} & : \text { 設計点流量 (最高効率点) } & {\left[\mathrm{m}^{3} / \mathrm{s}\right]} \\ D_{2} & \text { : 動翼の代表直径 } & {[\mathrm{m}]} \\ U_{2} & : \text { 動翼の代表直径における周速度（基準流速）} & {[\mathrm{m} / \mathrm{s}]} \\ H & : \text { 揚程 } & {[\mathrm{m}]} \\ g & : \text { 重力加速度 } & {\left[\mathrm{m} / \mathrm{s}^{2}\right]} \\ V e l & : \text { 相対速度 } & {[\mathrm{m} / \mathrm{s}]} \\ \text { step } & : \text { 計算ステップ数 } & {[-]} \\ C \mathrm{p} & : \text { 圧力係数 } & {[-]} \\ P & : \text { 圧力 } & {[\mathrm{Pa}]} \\ \rho & : \text { 流体の密度 } & {\left[\mathrm{kg} / \mathrm{m}^{3}\right]}\end{array}$




$\begin{array}{lll}z \text { imp } & : \text { 羽根車入口面からの軸方向距離 } & {[\mathrm{m}]} \\ \beta & : \text { 流れ角度 } & \text { [degree] } \\ \mathrm{Cu} & : \text { 絶対流れの周方向速度成分 } & {[\mathrm{m} / \mathrm{s}]} \\ \mathrm{AoA} & : \text { 迎え角, A Atack of angle } & \end{array}$

\section{3. 供試ポンプと解析条件}

\section{$3 \cdot 1$ 供試ポンプ}

供試ポンプは前報（萩谷他, 2016） と同一の比速度 $1000\left[\mathrm{~min}^{-1}, \mathrm{~m}^{3} / \mathrm{min}, \mathrm{m}\right]$ の斜流ポンプであり，図 1 に示す解 析モデルの斜視図のように, 動翼枚数 5 枚のオープン羽根車と静翼枚数 12 枚のディフューザ流路を有する. 羽根 車の上流側に直管状の吸込管があり，吸込管の中の羽根車直前に十字型の整流板がある，ディフューザ流路の下 流側は曲がり管を介して直管状の吐出管へつながっている.

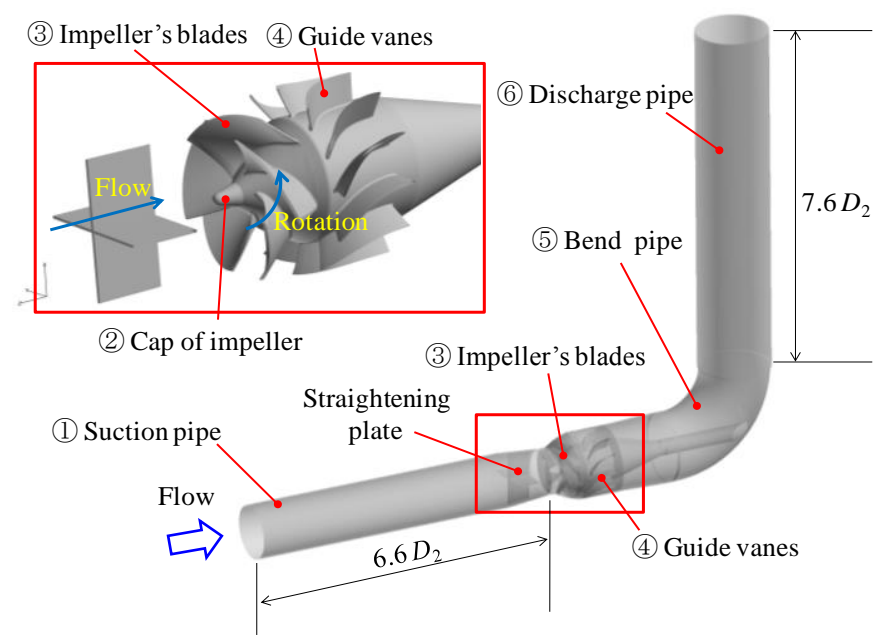

Fig. 1 Perspective view of computational model for test pump.

\section{$3 \cdot 2$ 解析領域と解析条件}

解析領域と解析条件は前報 (萩谷他, 2016) と同一である. 解析領域は図 1 に示すように, 領域(1): 吸込管領域, 領域(2)：羽根車キャップ領域，領域(3)：羽根車領域，領域(4)：案内羽根領域，領域(5)：曲がり管領域，領域(6)： 吐出管領域の 6 領域をオーバーセット法を用いて結合し, LES 解析を実施した. 領域(1), 領域(4), 領域(5)と領域 （6は静止系場とし，領域(2)と領域(3)は回転系場とした。流体解析プログラムには FrontFlow/blue（Kato et al., 2007; Guo et al., 2006）を用い，LES のスマゴリンスキー・モデルモデルにはダイナミック・スマゴリンスキー・モデル

（Dynamic Smagorinsky Model, DSM）を用いた. また, 運動方程式の解法にはクランク・ニコルソン法を用いた. 連続の式は Fractional step 法により解いたが，オーバーセット法に伴う非物理的な圧力波の発生を防止するため に低マッ八数近似（マッ八数 0.2）を導入した．また，壁面近傍での壁面モデルは用いなかった．境界条件とし ては，領域(1)の入口境界には一様な一定速度を与え，領域(6)出口境界には圧力 0 とトラクション・フリー条件 を与えた．隣接する領域同士は数格子分の幅で重なり合っており，オーバーセット法に基づいて計算中に速度と 圧力のデータを交換することにより，全体として連続した流れ場の計算が行われる. 壁面境界には non-slip 条件 を与えた. 時間刻みは 1 回転当たり 5,120 step となるように設定した.

全領域の計算格子の合計数は 760 万であり，羽根車領域の格子数は 230 万である. 代表として, 羽根車動翼の チップ前縁における格子の無次元距離は, 翼弦方向, 壁面垂直方向, スパン方向にそれぞれ，400, 400, 1000 であ る. 本研究で用いた計算格子の解像度は, Re 数が $10^{6}$ オーダーである羽根車動翼表面に発達する乱流境界層内の 渦挙動を解析するには, 粗く不十分である. しかし, 流路内にある大規模な渦の非定常的な挙動を再現すること 
Hagiya, Kato, Yamade, Fukaya and Nagahara, Transactions of the JSME (in Japanese), Vol.84, No.857 (2018)

は可能であり，全揚程が主として，羽根車部と案内羽根部の大きなはく離流れの挙動が主流に影響を与えること により決定されると仮定すれば，本研究で用いたような粗い計算格子による LES によっても，不安定特性の要因 となる現象の予測と発生メカニズムの分析が可能であると考えた。

流量は，最高効率点の流量 $Q_{\mathrm{BEP}}$ を $100 \%$ 流量と定義し，40\%流量～130\%流量の計 17 流量を計算し，特に不安 定特性が発生する流量である 60\%流量付近については，55\%，58\%，60\%，60.5\%，61\%，62\%，63\%，65\%の8 流量点でLES 計算を実施した。 1 回転あたり 64 個のデータをサンプリングし，統計処理することによって，非 定常内部流れを分析した.

\section{4. 揚程曲線の解析予測值と実測値の比較}

図 2 と図 3 に水力性能の計算值と実験值との比較を示す.これらの図は前報（萩谷他, 2016）でも示した図を 再掲した. 図 3 は不安定特性が発生する近傍の流量の拡大図である. 流量は最大効率点の流量 $Q_{\mathrm{BEP}}$ で規格化し て示した. 全揚程は入口（図 1 領域(1)の流入面）と出口（図 1 領域6の流出面）の全圧の流量平均值の差より 算出した. 解析結果の理論揚程は羽根車の上流（図 1 領域(2)の流入面）と下流（図 1 領域(3)の流出面）の角運 動量の流量平均值を求め, それらの差より算出した。したがって，ケーシング壁面における摩擦卜ルクが差し引 かれたものになっているがこの影響は無視できるほど小さい. 解析結果は $61 \%$ 流量と $60 \%$ 流量の間で顕著な右上 がり揚程特性（不安定特性）を示している。本研究では，図 3 中に示したとおり，61\%流量を（A）不安定特性 の開始点（Start point），60\%流量を（B）不安定特性の終点（End point）と定義した.さらに，この間の60.5\%流 量を（C）不安定特性の発達過渡時の流量点（Transitional point）として，特に詳細に内部流れを分析した.

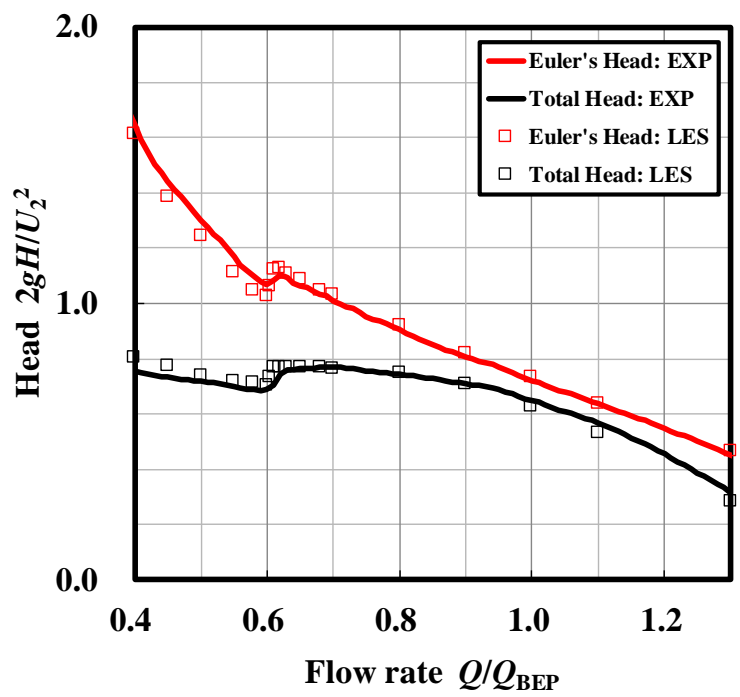

Fig. 2 Comparison of measured and computed Euler's head and total head. The measured and computed heads agree well each other. Both head curves have a positive slope at around $60 \%$ flow rate ratio.

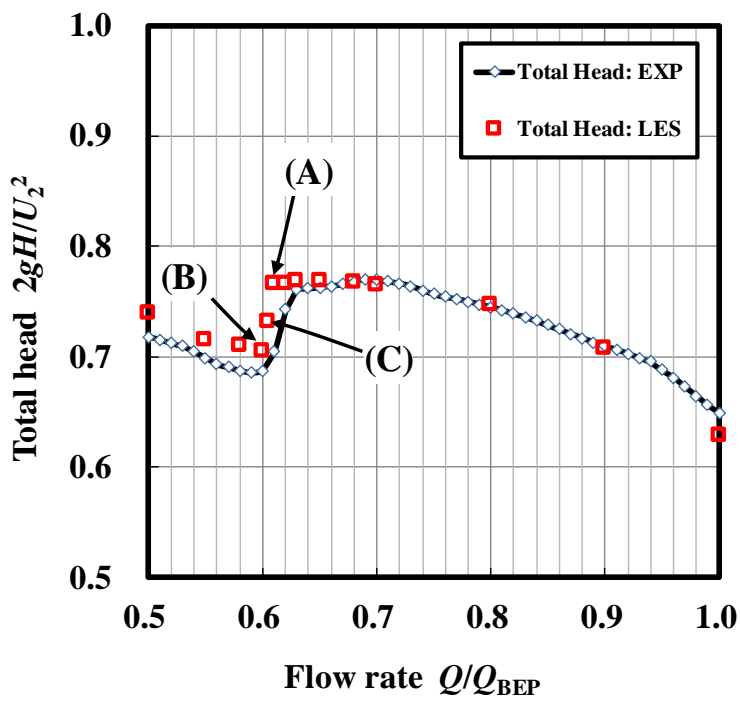

Fig. 3 Enlarged view of total head near instability point. (A), (B), and (C) respectively indicate, start, end, and transitional points of the positive slope.

\section{5. 不安定特性発達途中における非定常流れ場の分析}

不安定特性の主要因であると考えられる動翼の失速が発生するメカニズムを分析するため, 過渡状態である流 量点 $(60.5 \%$ 流量）の解析結果を用いて，動翼部内部流れの非定常変化を詳細に分析した. この流量点の羽根車 部チップ近傍においては，図４（前報（萩谷他, 2016）の図を再掲）に示すように，低速の流体塊に覆われた動翼 翼間と覆われていない翼間とが混在していることを前報にて報告している．図中に低速の流体塊に覆われた動翼 の翼間流路を点線で示した。 
Relative velocity $/ U_{2}$

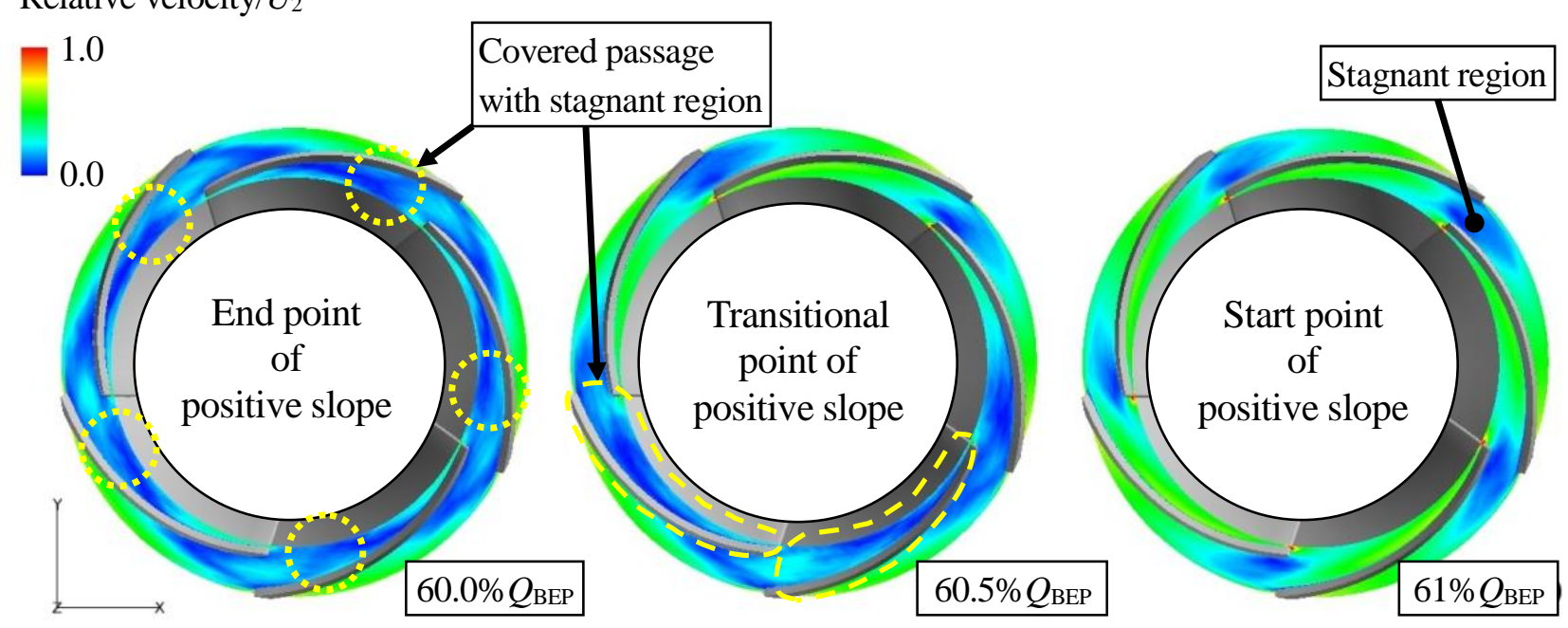

Fig. 4 Distribution of relative velocity on conical surface near blade tip around instability point $(60.0 \%, 60.5 \%, 61 \%$ flow-rate ratios). For $60.0 \%$ flow-rate ratio, stagnant regions cover all blade passages on the tip side. For $61 \%$ flow-rate ratio, no blade passages are covered with a stagnant region. For $60.5 \%$ flow-rate ratio, two passages are covered with stagnant regions.

\section{$5 \cdot 1$ 動翼の各翼間の理論揚程と流量の時間変化}

本節では，各翼間流路の理論揚程と流量の時間変化について，分析した結果を報告する. 図 5 に本報告におけ る動翼と翼間流路の定義を示す，ある時点において，ほぼ 12 時の方向にある動翼を blade 1 とし， blade 1 から時 計回り (羽根車の回転と逆向き)に blade 2 から blade 5 を定義した. また, blade 1 と blade 2 との翼間流路を passage 1 (図中では pass 1 と表記）と定義し，動翼と同様に，時計回りに passage 2 から passage 5 を定義した。つまり， 各動翼の負圧面側の流路を動翼と同じ番号を付けて称する.

（C）不安定特性の発達過渡時の流量点（Transitional point）における，各動翼翼間流路の理論揚程と流量の時 間変化をそれぞれ図 6 と図 7 に示す。これらの值は羽根車 1 回転分の移動平均処理を施した值である. 図 2 お よび図 3 に示した理論揚程と同じく, 理論揚程は翼間流路の入口と出口の間の角運動量の増加量から算出した. さらに図中に，各翼間を時間平均し，かつ全翼間を平均した值を示す．各図において，(a)は羽根車の元の位相に 対して理論揚程や流量を示したものであり，(b)はそれらを passage 1 から 1 翼間分離れる毎に羽根車 4 回転分左 向きにオフセットして示したものである. 理論揚程，流量ともに平均值の $\pm 10 \%$ 程度変動している. 図 6 （b） と 図 7 （b）より，理論揚程と流量はともに，1 翼間当たり 4 回転分時間をオフセットすることで, 各翼間の波形 が概ね一致することがわかる。このことから，ここで見られる現象は羽根車が 4 回転する間に 1 翼間移動してお り, 20 回転する間に 5 翼間 (羽根車 1 周分) 移動していることがわかる. 寸なわち, 羽根車回転数のおおよそ $1 / 20$ の速度で羽根車と逆向きに伝播していることがわかる. また, 理論揚程の時間変化と流量の時間変化は明らかに 相関を持っており, この点に関しては後述する.

次に，(A）不安定特性の開始点である $61 \%$ 流量と（B）終了点である $60 \%$ 流量における各翼間流路の理論揚 程の時間変化を図 8 に示す. 理論揚程は図 6 (a) と同様の移動平均処理をした值である. 図 6,7 と同じく図中 に，各翼間を時間平均し，かつ全翼間を平均した值を示す．図 6 (a)，および図 8 (a)，（b）より，不安定特性 の 発達過渡時（60.5\%流量）における理論揚程の変動幅（0.14）は開始点や終了点での值（それぞれ 0.071 と 0.083 ) よりも大きく, 不安定特性の発達過渡時において変動が最大となる. また, 発達過渡時における理論揚程の最大 值は不安定特性の開始点（61\%流量）における最大值より若干大きく $(0.63)$, 一方, 最小值は終了点 (60\%流量) における最小值 より若干小さい（0.49）ことから，発達過渡時には，各翼間流路の状態が不安定特性の開始点に 近い状態と終了点に近い状態との間で交互に変化しているものと考えられる. なお, 不安定特性の開始点である 61\%流量と終了点である $60 \%$ 流量においては, 各動翼流路の理論揚程の時間変化が羽根車の位相をオフセットす ることによりほぼ一致することはなかった。したがって，これらの流量においては羽根車内を旋回する前記現象 
は生じていないものと考えられる．以下，不安定特性の発達過渡時の流量点（Transitional point）において発生 している，羽根車内を旋回する前記現象を解明するために，この流量における動翼翼間流れを分析した結果を説 明する。

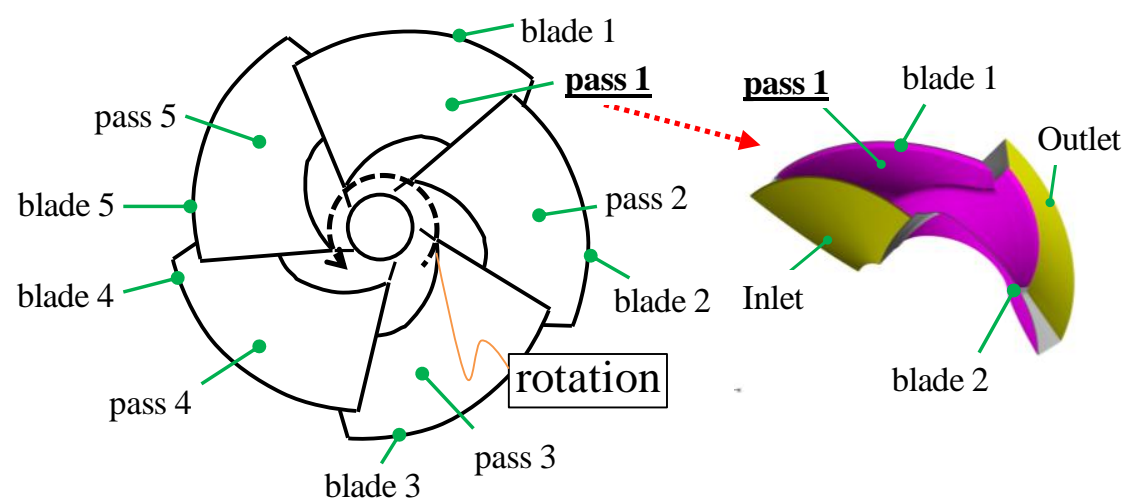

Fig. 5 Naming rule for blades and blade passages

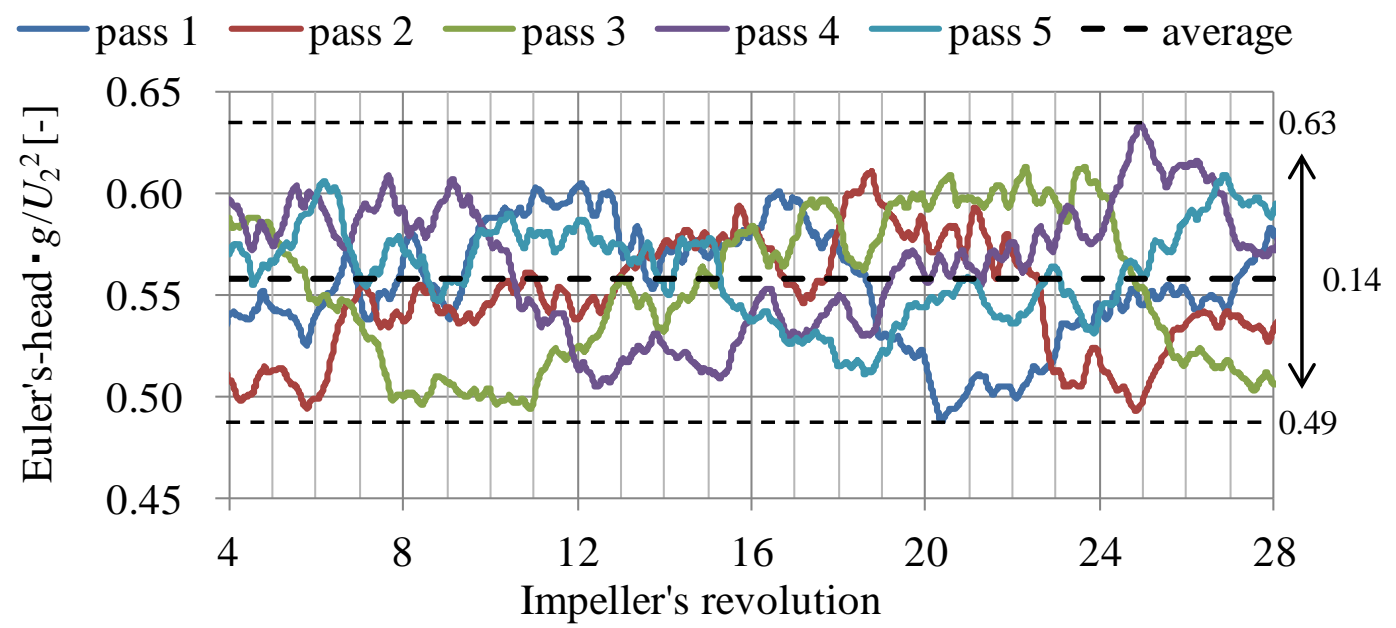

(a) Raw data

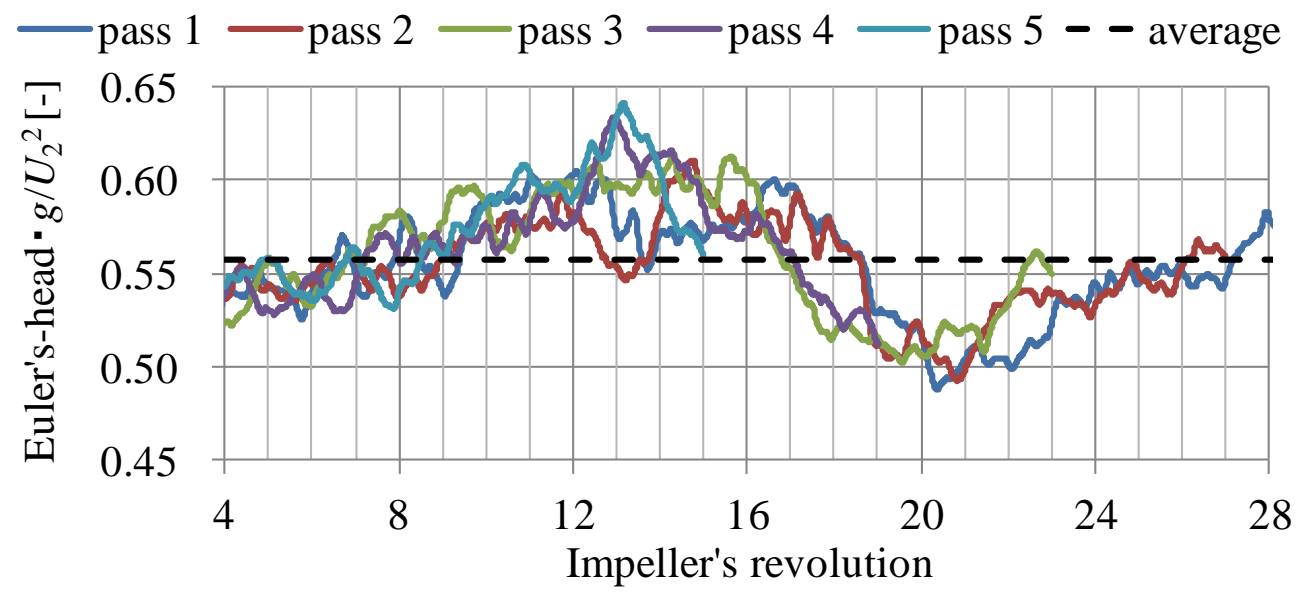

(b) Offset data

Fig. 6 Variation of Euler's head of each blade passage with respect to impeller's revolution at transitional point of positive slope $\left(60.5 \% Q_{\mathrm{BEP}}\right)$. The Euler's heads of passage 2 through passage 5 are plotted with an offset respectively of $4,8,12$, and 16 impeller's resolutions in (b), where their Euler's heads approximately correspond with each other. Therefore, condition of the high Euler's head propagates to the next blade passage while the impeller makes approximately 4 revolutions. 


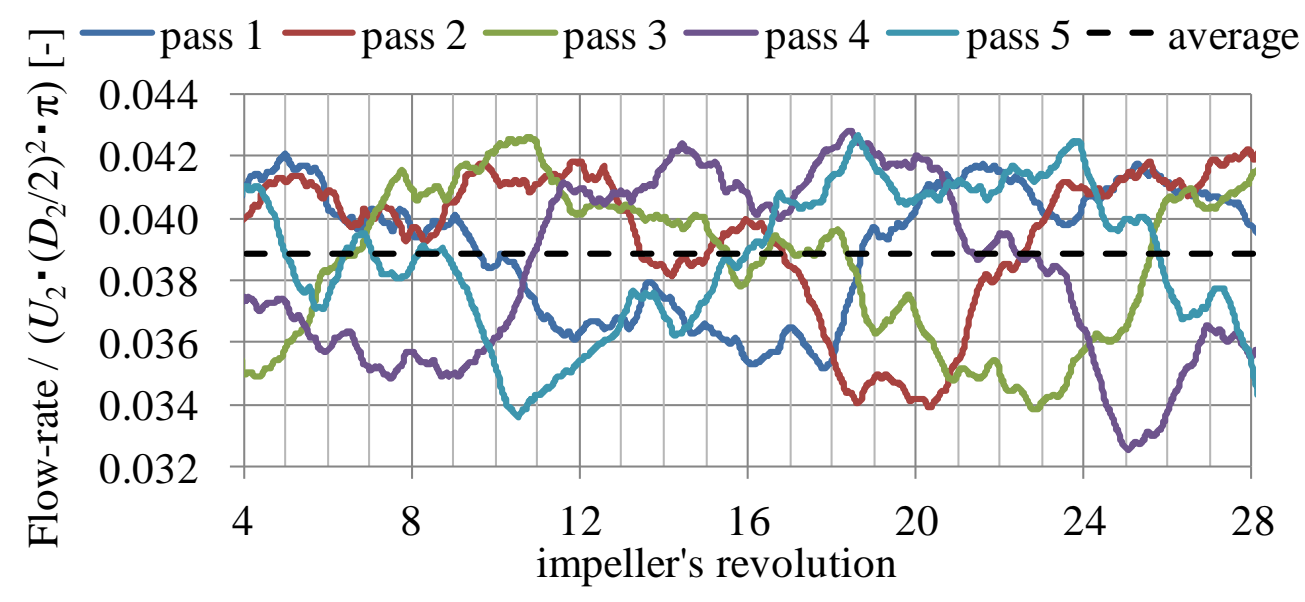

(a) Raw data

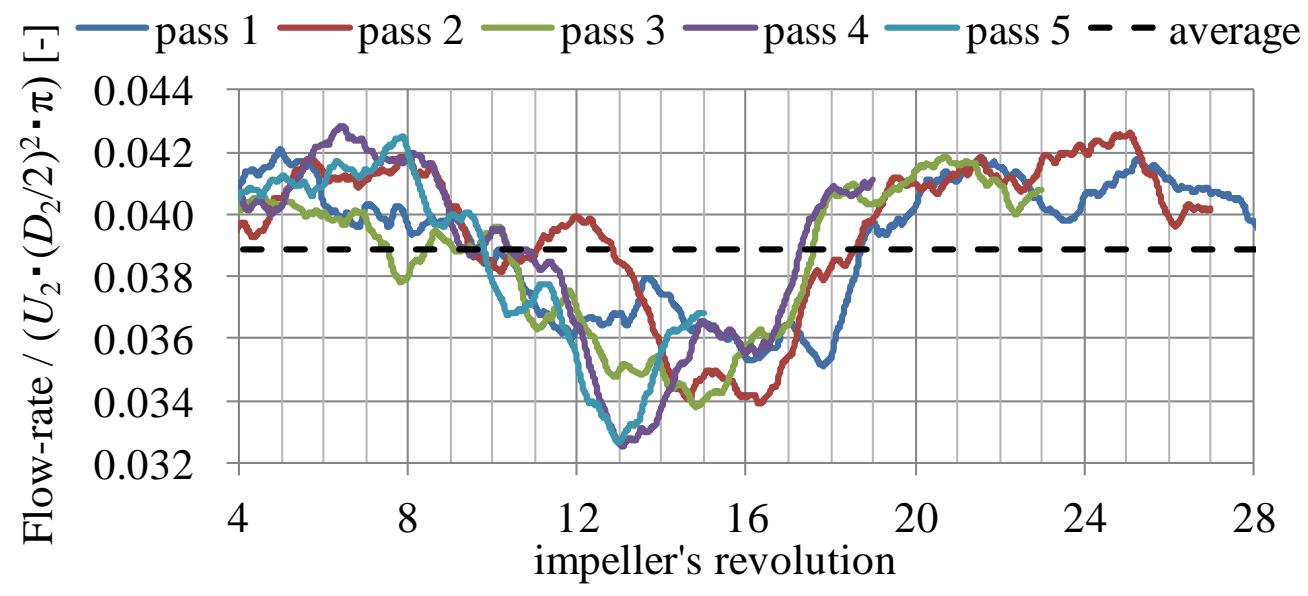

(b) Offset data

Fig. 7 Variation of flow-rate through each blade passage with respect to impeller's revolution at transitional point of positive slope $\left(60.5 \% Q_{\mathrm{BEP}}\right)$. The flow-rates of passage 2 through passage 5 are plotted with an offset respectively of $4,8,12$, and 16 impeller's resolutions in (b), where their flow-rates approximately correspond with each other. Therefore, condition of the low flow rate propagates to the next blade passage while the impeller makes approximately 4 revolutions. 


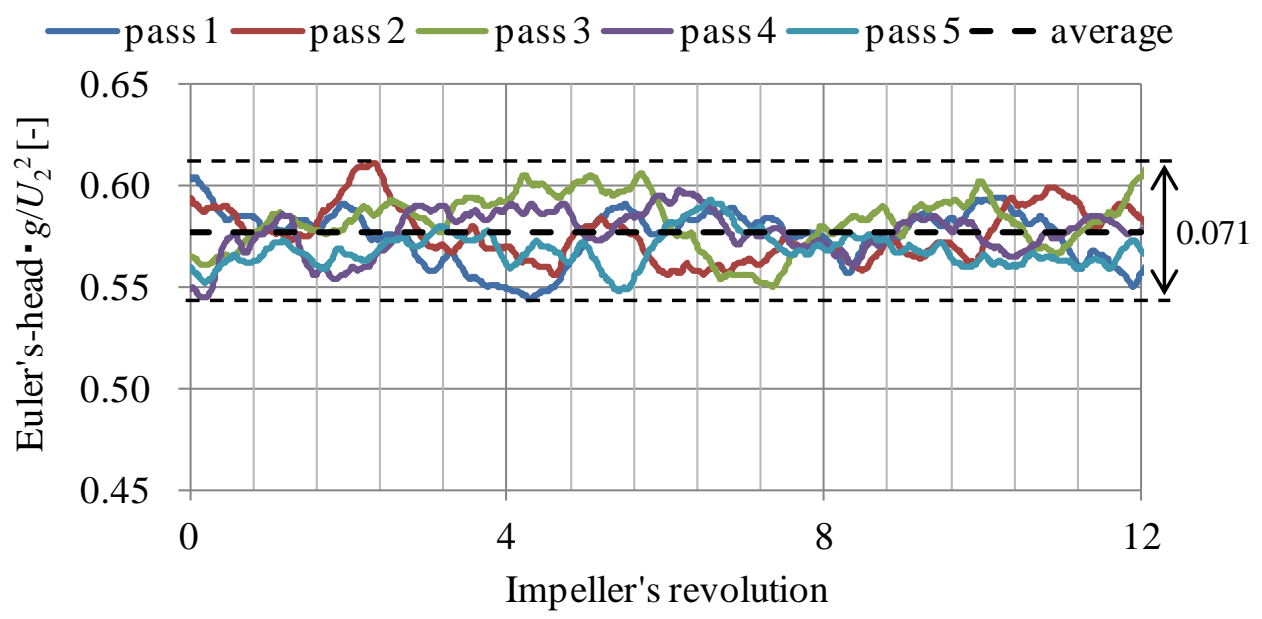

(a) Start point of the positive slope $\left(61 \% Q_{\mathrm{BEP}}\right)$

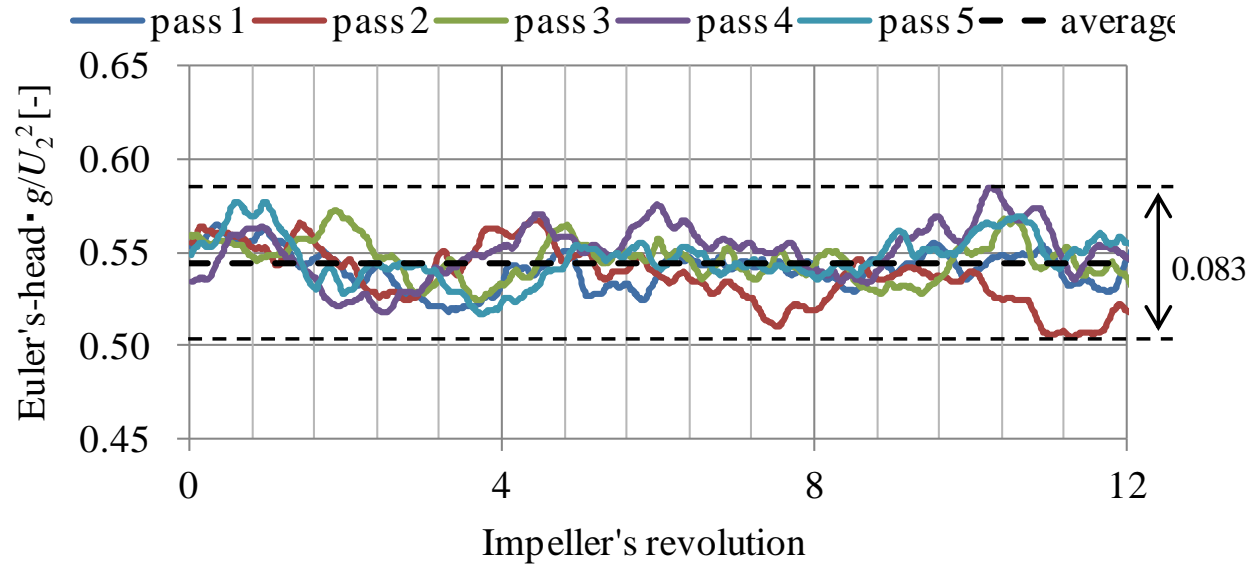

(b) End point of the positive slope $\left(60 \% Q_{\mathrm{BEP}}\right)$

Fig. 8 Variation of Euler's head of each blade passage with respect to impeller's revolution at start (a) and end (b) points of positive slope. The maximum amplitude in the Euler's head are 0.071 and 0.083 , respectively for the start and end points of the positive slope. These are smaller than that (0.14) for the transitional point shown in Fig. 6 (b).

60.5\%流量における各動翼チップ側の圧力分布（翼負荷分布）を羽根車 4 回転ごとに図 9 （a）から（d）に示 す.また，比較のために $60 \%$ 流量における羽根車 4 回転目の圧力分布を同図（e）に示す．縦軸の圧力は以下の 式（1）に示すように基準静圧 $P_{\infty}$ との差を動翼代表直径 $D_{2}$ の周速 $U_{2}$ に対する動圧で無次元化した值であり，一 方，横軸は羽根車入口面からの軸方向距離を動翼の代表直径 $D_{2}$ で割った值である。（a）に示した $60.5 \%$ 流量の 4 回転時においては，図中に「stall」と示した「blade 4」と「blade 5」の前縁の負荷が低下しており，失速している ことが確認される．なお，本論文では動翼の前縁負荷が低下している場合にその動翼は失速していると称し，ま た，翼間流路の流量が低下している場合にその流路は失速していると称している．（b）〜（d）に示した 60.5\% 流量の 8 回転時, 12 回転時, 16 回転時の圧力分布から, 羽根車が約 4 回転する間に動翼の失速状態は羽根車の回 転とは逆向きに動翼 1 ピッチずつ伝播することが確認される. 動翼枚数は 5 枚であるため, 失速は羽根車が約 20 回転する間に羽根車の回転方向とは逆向きに 1 回転することになる.つまり, 動翼の失速は羽根車の旋回速度 に対して約 $5 \%$ の遅い旋回速度で旋回していることになる. 失速の旋回速度が遅い理由に関する考察は後述する. なお，（e）に示した不安定特性の終了点である $60 \%$ 流量では全ての動翼で前縁の負荷が低下しており, 失速し ていることが確認される. 
$C_{\mathrm{p}}=\frac{2\left(P-P_{\infty}\right)}{\rho U_{2}^{2}}$

- blade 1 - blade $2 \bullet$ blade 3 - blade $4 \bullet$ blade 5

- blade $1 \cdot$ blade $2 \cdot$ blade $3 \cdot$ blade 4 -blade 5

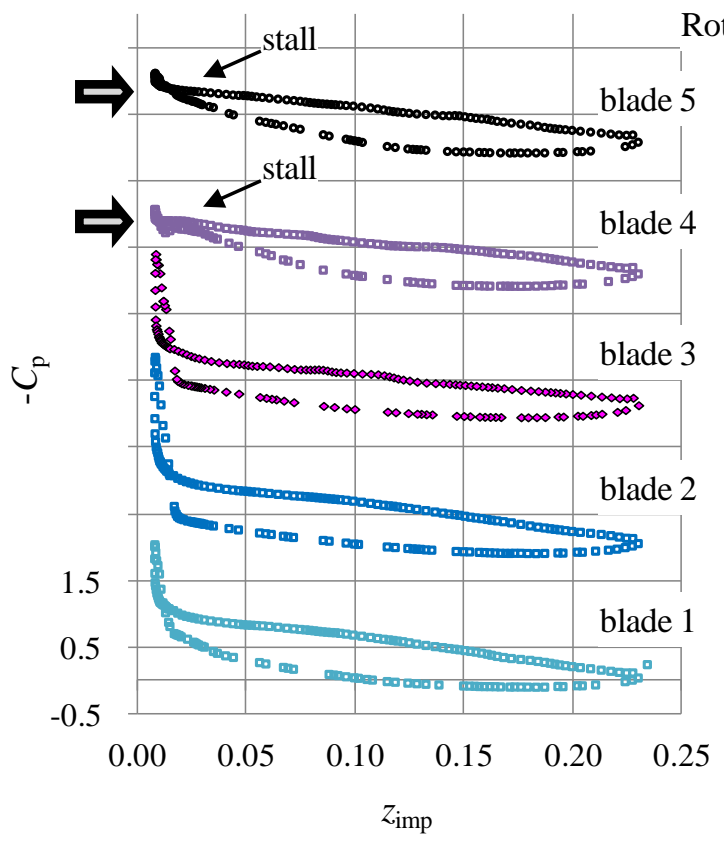

(a) 4 revolution for $60.5 \%$ flow rate

- blade 1 - blade $2 \cdot$ blade 3 - blade 4 - blade 5

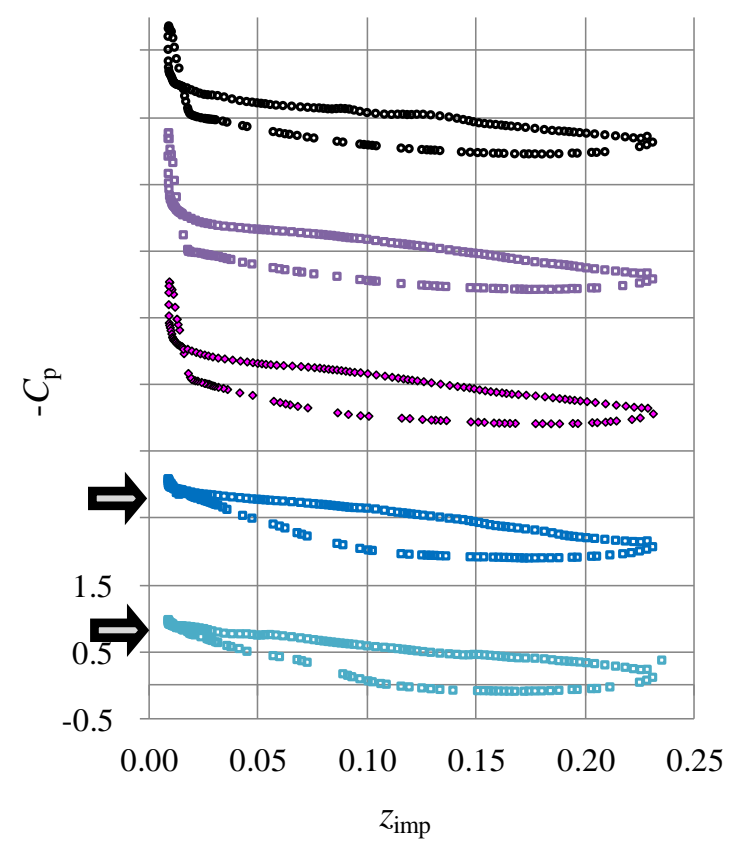

(c) 12 revolution for $60.5 \%$ flow rate

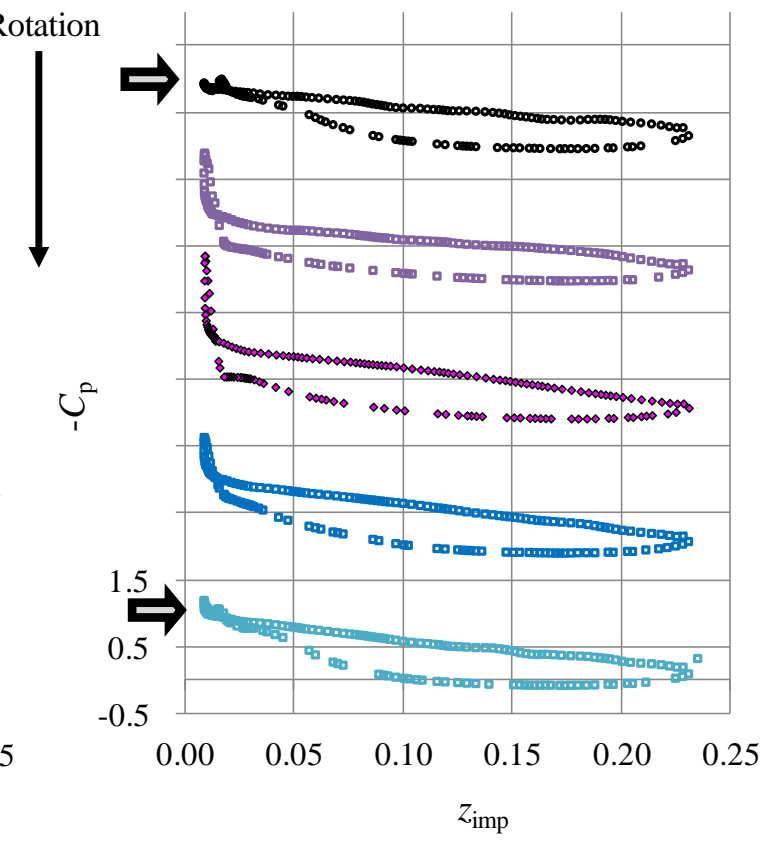

(b) 8 revolution for $60.5 \%$ flow rate

- blade 1 - blade $2 \bullet$ blade $3 \circ$ blade $4 \cdot$ blade 5

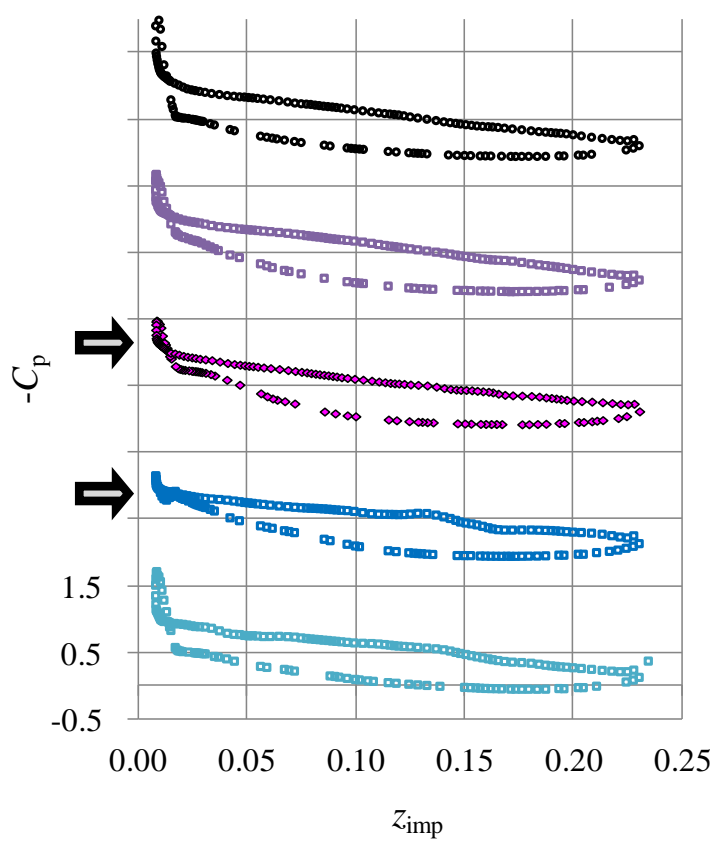

(d) 16 revolution for $60.5 \%$ flow rate 


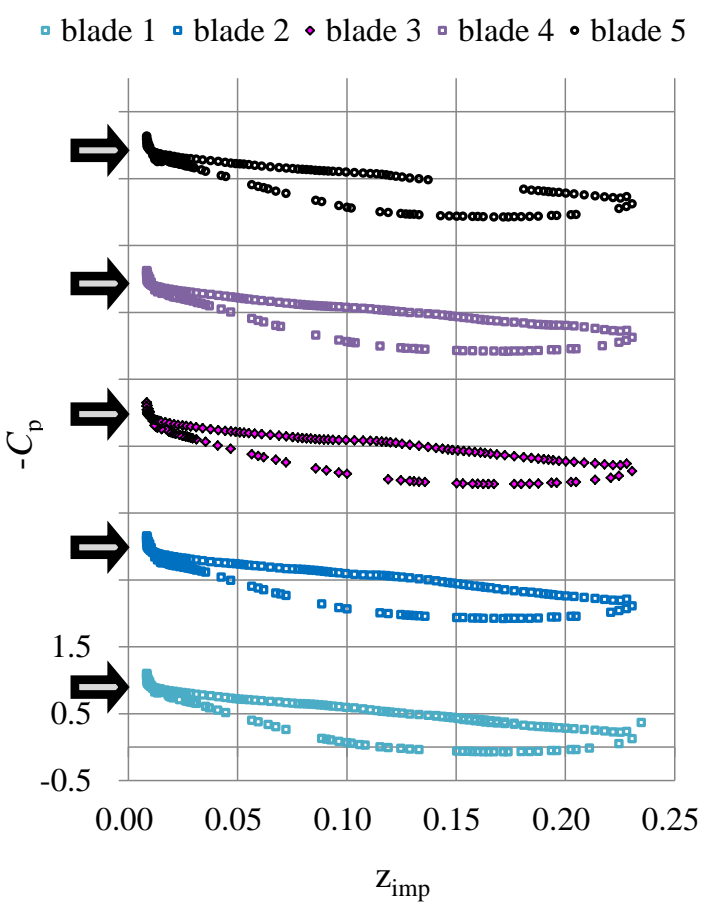

(e) 4 revolution for $60 \%$ flow rate

Fig. 9 Evolution of pressure distributions near tip of each blade for $60.5 \%$ flow-rate ratio (Fig. 9-(a) to Fig. 9-(d)) and that at 4th impeller's revolution for $60.0 \%$ flow-rate ratio (Fig. 9-(e)). For $60.5 \%$ flow-rate ratio, blade loads near the leading edge are small for blade 4 and blade 5 at 4th impeller's revolution and those are small for blade 5 and blade 1 at 8 th impeller's revolution, which indicates that the blade stall propagates to the neighboring blades in the opposite direction to the impeller's rotation while the impeller makes 4 revolutions. To the contrary, for $60.0 \%$ flow-rate ratio, all the blades are stalled at 4th impeller's revolution.

次に，動翼の負荷の変化と動翼翼間流れの変化との関係を調查するために，60.5\%流量における動翼チップ近 傍の円錐断面内の相対速度分布，流れ角度分布，ならびに圧力分布をそれぞれ図 10 (a) から（d）に示す．これ らの図の左側は羽根車 4 回転時の流れを示し，右側は 8 回転時の流れを示す。なお，流れ角度は羽根車の周速度 と逆向きの接線方向を 0 度と定義し, 図で半時計まわりの向きを正とした。図 10 (a) の相対速度分布によると， 低速領域で覆われ失速状態にある翼間流路が羽根車の回転と逆向き（passage 3,4 から passage 4, 5）に移動してい る.このとき, 点線の矢印で示す様に, blade 5 の負圧面側の 後縁で発生した低速領域が発達して前縁側に拡大 し, 翼間流路全域を覆う様子が観察され, 後縁型失速であることが明らかとなった. 後縁型失速が発生した理由 は，図 9 に示したように，動翼後縁側の負荷が比較的高いためであると思われる. また，一点鎖線の矢印で示す ように，羽根車 4 回転時には負圧面側の 翼間流路全域が低速領域で覆われていた blade 3 では，前縁から後縁に 向かって低速領域が消えていく様子が観察された。図 10 (b) には流れ角度分布を示し, 困 10 (c) には速度べ クトルを追加した図 10 （b）中の blade 1 前縁の拡大図を示した. 図 10 （b）と図 10 (c) によると, 図中 A と示 した領域では動翼負圧面から流れがはく離しているために 流れ角度が著しく大きくなっている. 特に, 負圧面で 流れがはく離する動翼の負圧面側の翼間の流れの向きはほぼ周方向になるため, 図 10 (a) において中抜きの矢 印により示した様に, 羽根車の回転と逆向きの方向で隣接する動翼の迎え角が大きくなる. 図 10 (d) の静圧分 布によると, 図中 B と示した低速領域で覆われた翼間流路の前縁側は圧力勾配が小さくなっている. 動翼が失速 すると流れを転向しなくなるため，圧力も上昇しなくなるためである．その後に，圧力勾配（圧力の上昇）が小 さくなることで再び翼間流を通過する流量が増大し始めると考えられるが, それに関しては次の図 11 にり詳述 する. 

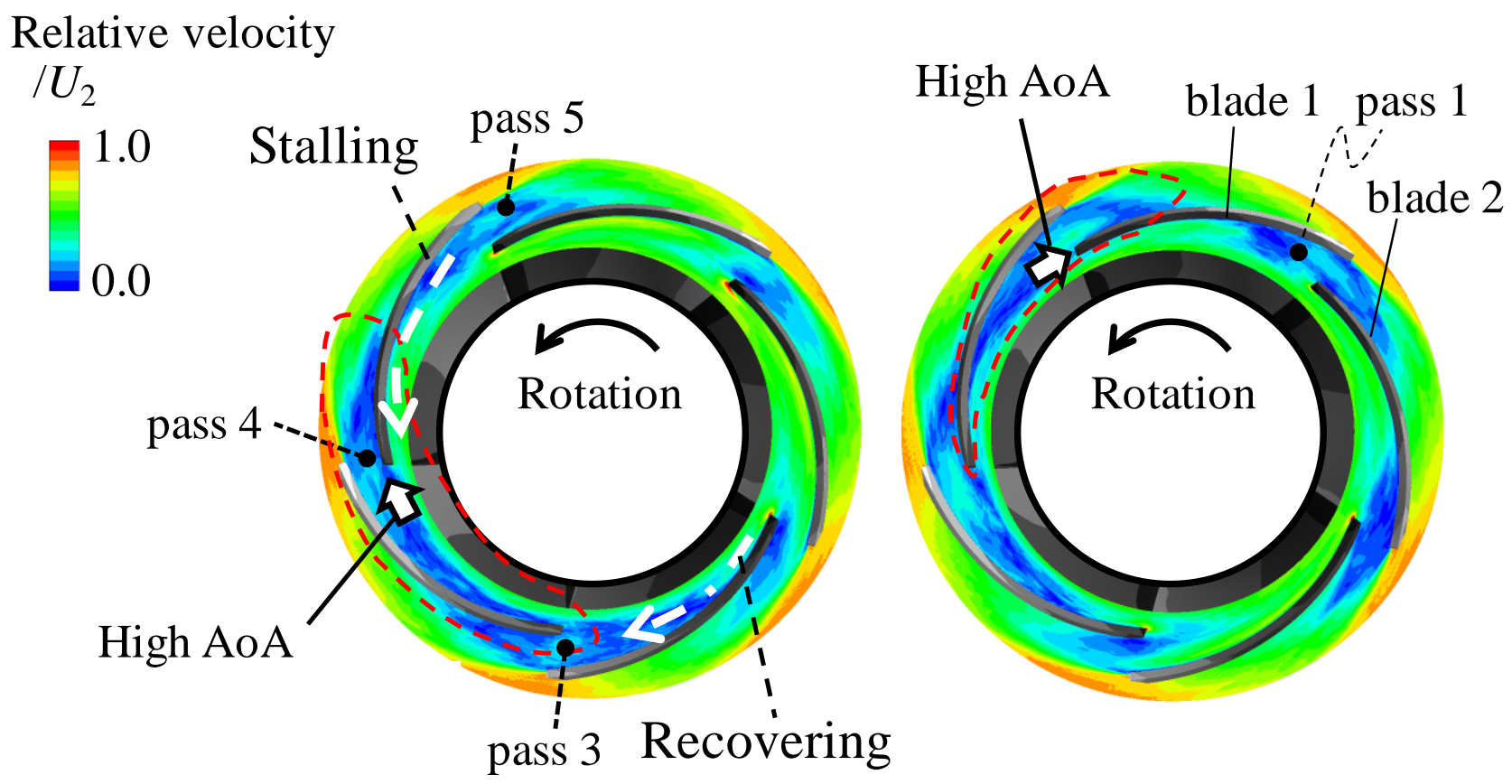

(a) Distribution of relative velocity
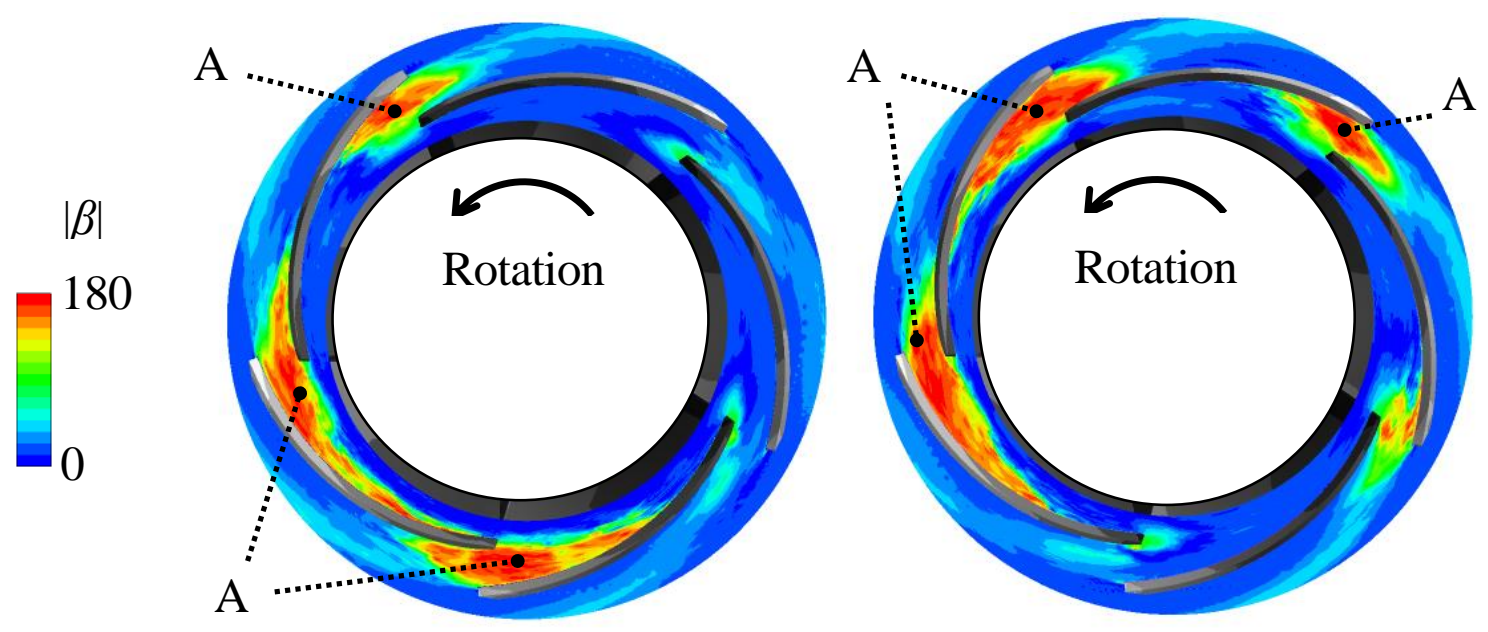

(b) Distribution of flow angle
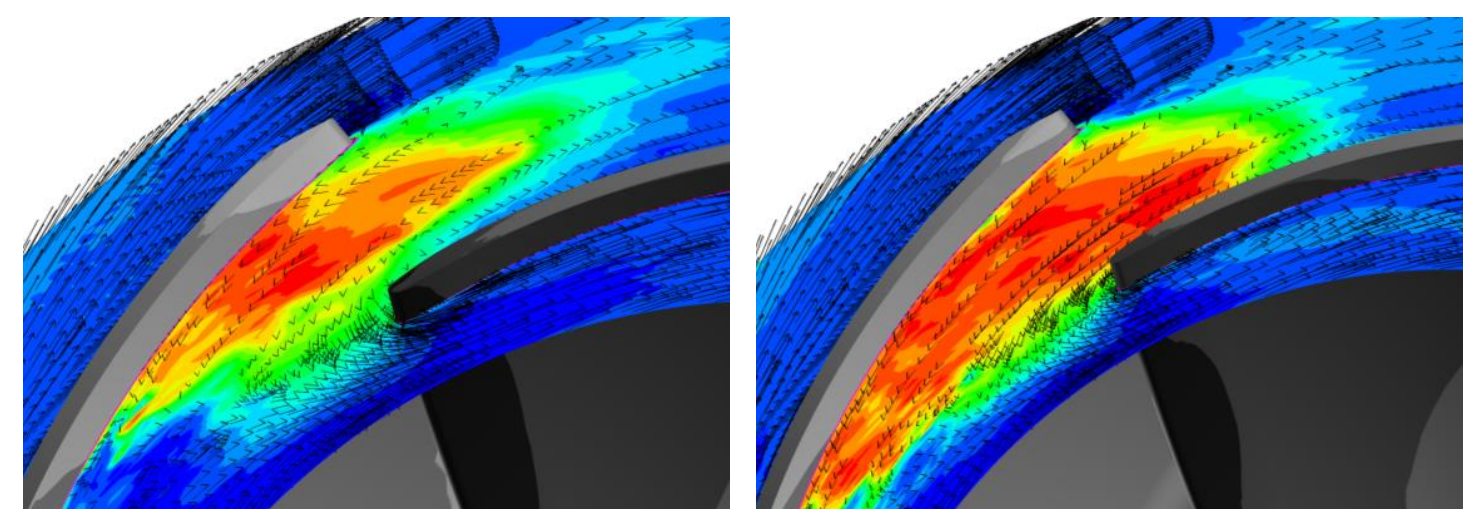

(c) Enlarged view of L.E. of blade 1 in figure (b) which velocity vectors are added to 

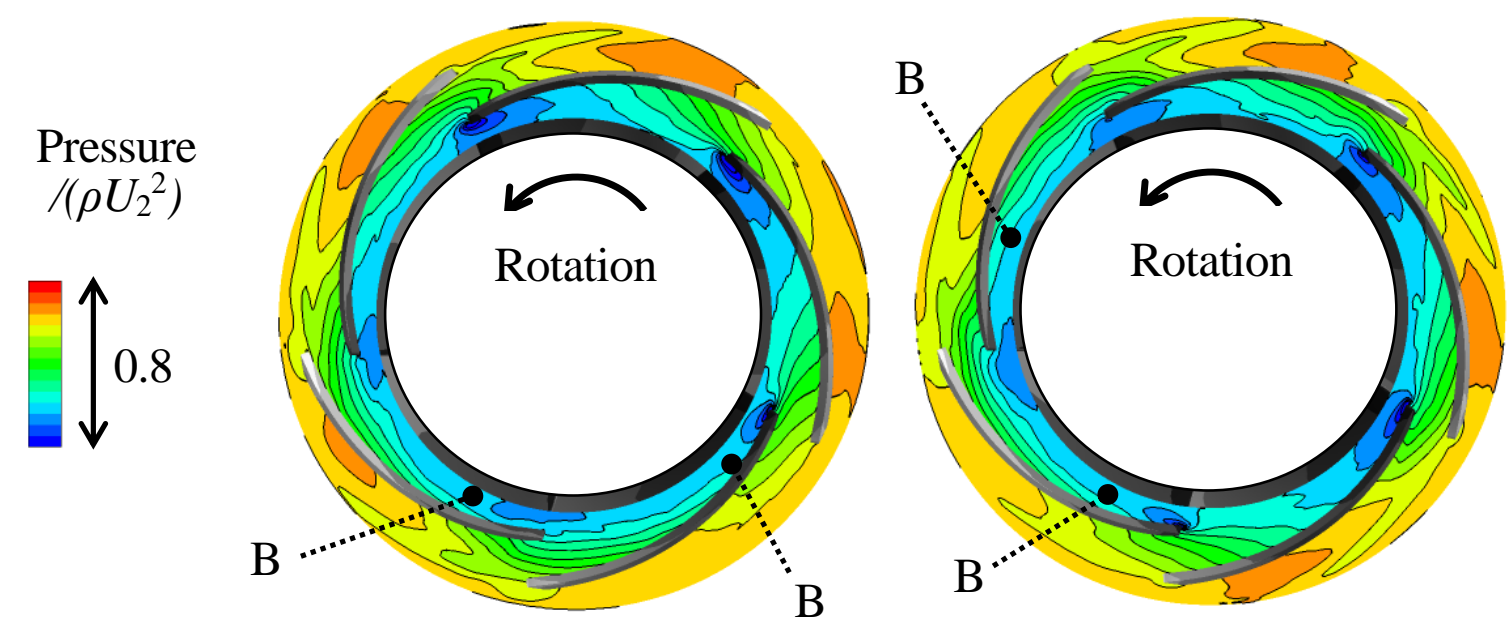

(d) Distribution of static pressure

Fig. 10 Instantaneous flows in blade passages near blade tip at $4^{\text {th }}$ (left) and $8^{\text {th }}$ (right) impeller's revolution for $60.5 \%$ flow-rate ratio. (a) Regions with low velocity first appear near the trailing edge and expand toward the leading edge. They propagate in the direction opposite to impeller's rotation (from passages 3 and 4 to passages 4 and 5). (b) The flow angles are high in the low-velocity regions. AoA of the neighboring blade in the direction opposite to the impeller's rotation will increase. (d) Positive pressure gradients near the leading edge are low in passages with low-velocity regions.

各動翼翼間の流入角および圧力分布を比較し易く寸るために, 前縁部における流入角の周方向分布と図 10 に示 した圧力分布を円筒面に展開した結果とを図 11 に示寸.この図 11 は特に動翼前縁近傍の圧力勾配を比較するこ とを目的としているが，ほぼ全翼弦長にわたり翼間流れを表示している．なお，図中の矢印は動翼に流入する相 対流れの向きを表す.この図 11, ならびに前掲の図 7, 図 9, および図 10 から, 失速や失速からの回復は以下の ようなメカニズムで動翼翼間を伝播していくものと理解できる.なお，各言及において参照した図を括弧内に示 寸．図 9 (a) からわかるように，羽根車 4 回転時においては，blade 4 と blade 5 が失速している，一方，翼間流 路については図 7 (a) および図 10 (a) からわかるように, この羽根車 4 回転時において, passage 3 は失速から 回復しつつあり, passage 4 は完全に失速しており，また passage 5 は失速しつつある.

まず，blade 5 ならびにその負圧面側の翼間である passage 5 に注目する．羽根車 4 回転時において，blade 5 前 縁の負荷は既に低下しているが（図９（a)），負圧面側のはく離領域（低速な流体領域）は後縁から前縁に拡大し 続けており（図 $10 （ \mathrm{a})$ )，その負圧面側の流路である passage 5 の流量は減少している（図７（a)）。このことによ り, passage 5 を介して blade 5 と対向する blade 1 に流入する流れが周方向に向くようになり（図 10 (a) および 同図 (b) ), blade 1 の負荷が増大寸る. このため, blade 1 の負圧面後縁近くから流れのはく離が始まり, 前縁ま で徐々にはく離領域が拡大寸る（図 10（a）および同図（b)）。羽根車 8 回転時において, blade 1 の前縁負荷は低 下しており失速しているが（図９（b)），その負圧面側の翼間流路である passage 1 の流量はまだ減少を続けてい る (図 7 (a))。これが羽根車の回転方向と逆向きにある動翼翼間に失速状態が伝播するメカニズムである.

次に, blade 3 ならびにその負圧面側の翼間である passage 3 に注目する. 前述のように羽根車 4 回転時において passage 3 の流量は増大しつつあり（図 7 (a)), passage 3 は失速した状態から回復し始めている. この時点におい て, blade 3 の前縁負荷は既に増大しているが（図 9 (a))，このことはblade 3 前縁負圧面側ではく離していた流 れが再度付着している（図 10 (a) ) ことを意味している。しかし, blade 3 の翼負荷は blade 2 や blade 1 と比較す るとまだ小さい (図 9 (a))。このため, blade 3 負圧面側の翼間である passage 3 の圧力上昇は blade 2 や blade 1 の負圧面側の翼間である passage 2 や passage 1 の圧力上昇と比べると小さい（図 11 (a))。すなわち, passage 3 には流れ易い条件が整っている。この時点において, passage 4 の圧力上昇も passage 2 や passage 1 の圧力上昇と 
比較すると小さいが（図 11（a)），前述のように，passage 4 を形成する blade 4 前縁の流れが負圧面ではく離して いるために, passage 4 には流量が増大寸る（失速から回復する）条件が整っていない. 一方, 羽根車全体の流量, 寸なわち, passage 1 から passage 5 の流量の総和は変わらないため, 失速状態にあって流量が少なくなっている翼 間, passage 3 ならびに passage 4 の流量を補うために, 羽根車内の他の翼間の流量が増大寸る. 上記のように, passage 3 が最も流量が増大し易い条件が整っているため, passage 3 の流量が選択的に増大寸る (図 7 (a)). passage 3 の流量が増大寸ることに伴い, blade 3 負圧面側のはく離点が後縁側に移動し（図 10 (a)), 羽根車 8 回転時に おいては，blade 3 負圧面側の流れは後縁まで付着し（図 10（a）および同図（b)），それに伴い， blade 3 の翼負荷 もこの時点で増大寸る (図 9 (b)). blade 3 負圧面側の流れが後縁まで付着したものになる (図 10 (a) ) ことに より, 羽根車 8 回転時において, blade 4 に流入する流れの迎え角が減少する (図 10 (b)).このことにより, blade 4 前縁から負圧面に回り込む流れが再度付着し（図 10 (a) および同図 (b)), blade 4 の前縁負荷が増大寸る（図 9 (b)). この時点においては passage 4 の翼負荷はまだ小さく(図 9 (b)), 圧力上昇も大きくないため (図 11 (b)), passage 4 が最も流量が増大し易い翼間となり, passage 4 の流量が増大寸る (図 7 (b)). 以上が失速状態から回復 する翼間が旋回していくメカニズムである.
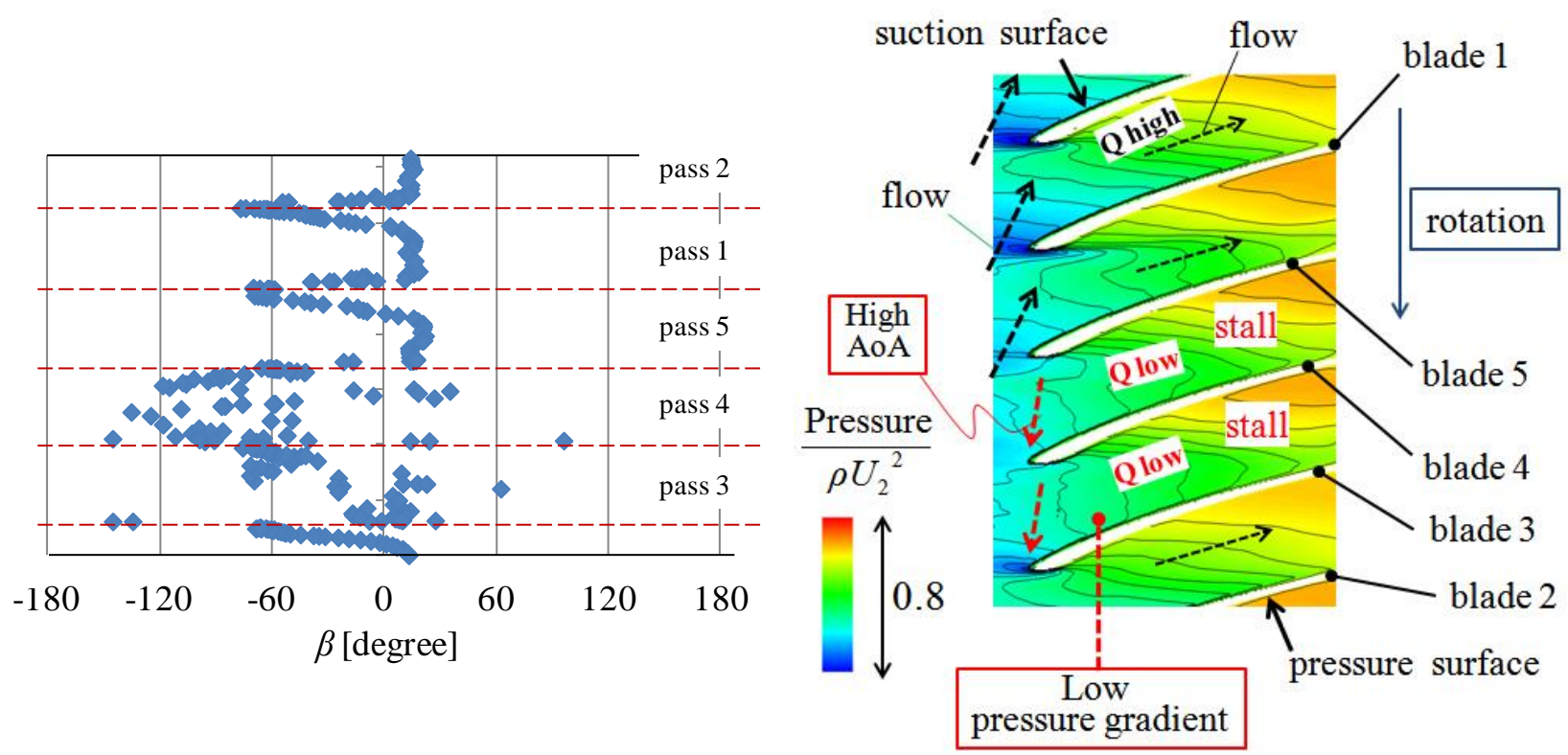

(a) $4^{\text {th }}$ impeller's revolution
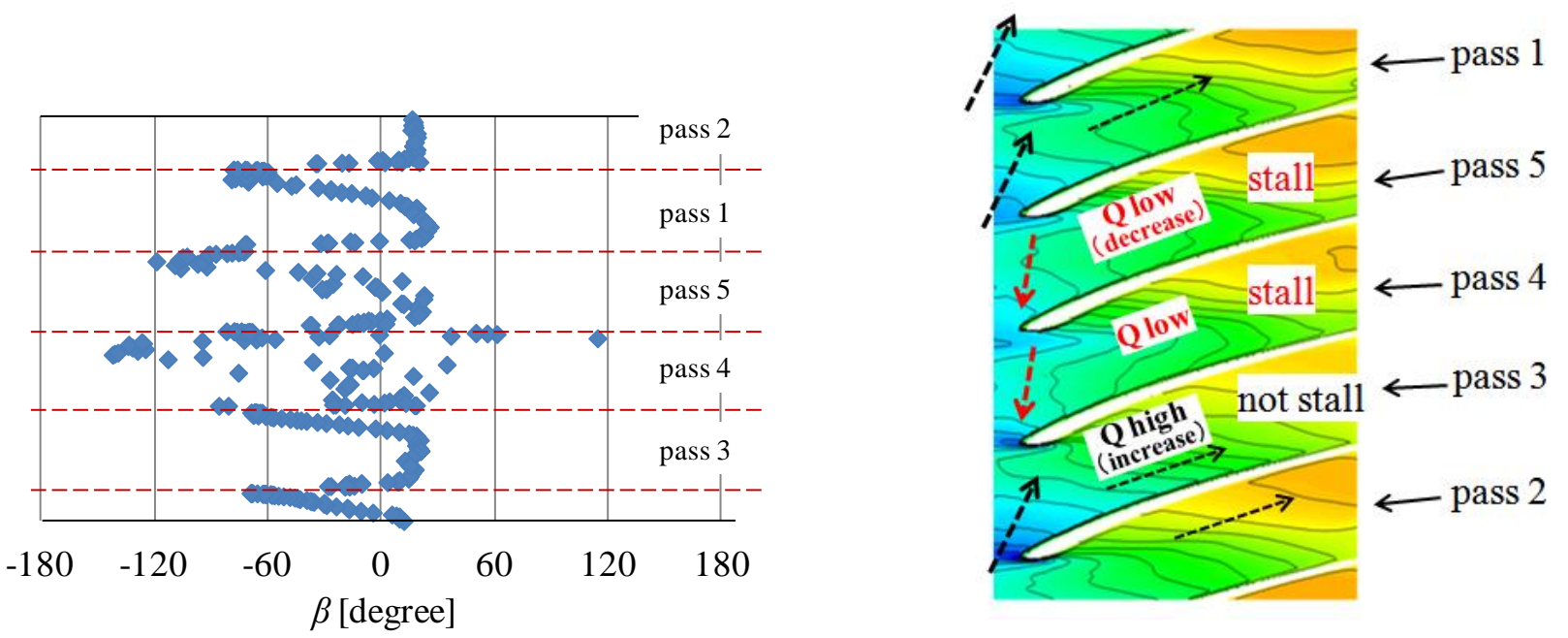

(b) $8^{\text {th }}$ impeller's revolution

Fig. 11 Instantaneous flow angle at L.E. (left) and pressure distributions of blade passages expanded onto cylindrical surface (right) at $4^{\text {th }}$ and $8^{\text {th }}$ impeller's revolution for $60.5 \%$ flow-rate ratio 
前記失速が進行する過程と失速から回復する過程が羽根車動翼内を旋回するメカニズムに追加して, 各動翼の 理論揚程と旋回失速との関係について考察する. 前掲の図 7 (b) によると, 各動翼翼間は羽根車 6 回転時から 16 回転時にかけて流量が減少（失速が進行）し，同 16 回転時から 26 回転時にかけて流量が増大（失速状態から回 復）している。（ただし，以降の議論において羽根車回転数はオフセットした值を用いている．また，羽根車の 回転時の值は概略の值である。）一方，図 6（b）によると，各翼間の理論揚程は翼間流量が減少し始める時（羽 根車 6 回転時）には既に増加しつつあり, 羽根車 13 回転時から減少に転じ，その後，羽根車 21 回転時から再び 増加している，つまり，各翼間の流量の時間変化と理論揚程の時間変化はおおむね負の相関を持っているが，理 論揚程の変化の方が羽根車 5 回転程度早く位相が進んでいる. このことは, 負圧面後縁近傍ではく離が生じると 絶対流れの旋回速度成分が大きくなり，理論揚程は直ちに増大し始めるが，翼間の流量が減少し始めるのははく 離点がある程度前縁に移動してから起こることを意味している.

以上，不安定特性発生の過渡時において，動翼負圧面側後縁近傍から発生寸るはく離領域の拡大（はく離点の 前縁へ向けた移動）と縮小（はく離点の後縁へ向けた移動）が羽根車内の動翼翼間で順次発生し，このことによ り，失速状態が羽根車内を旋回することを明らかにした．この失速セルが旋回するメカニズムは，Paco 等（Paco et al., 2017）が明らかにした, 低流量のポンプ運転時にポンプ水車のディフューザ流路内で失速セルが旋回するメ カニズムと同じである．回転翼列であっても静止翼列であっても失速セルが旋回するメカニズムが同じである点 は興味深い. なお, Paco 等が対象としたポンプ水車における失速セルの旋回速度は羽根車回転数の約 $2 \%$ ある.

Paco 等は失速セルの旋回速度を定量的に予測するためには境界層内の縦渦を解像することが重要であることを 見出し，特に，失速した状態から回復を始めるまでの時間が境界層の縦渦の解像度により大きく異なることを報 告している（Paco et al., 2017）。彼等は比較的大規模な流れである失速セルの挙動はレイノルズ数に大きく依存 しないものと仮定し, レイノルズ数を実際の 25 分の 1 にすることにより, 実験值と良く一致する失速セルの旋回 速度を得たと報告している．本研究では失速セルの旋回速度に関する実験データの取得が困難であったため実験 との比較は行っていないが，失速セルの旋回速度に関してはさらなる研究が必要であると考える．Paco 等が言及 している失速状態から回復を始めるまでの時間に関して，はく離点の直ぐ下流の境界層は間欠的にはく離と付着 を繰り返しており，境界層の解像度が十分にあると縦渦が再現され，縦渦が壁面近傍に持ち込む運動量によって 付着した状態が維持されると推定しており，この仮説の検証に関しては後報にて報告したい. また，羽根車内で 発生する旋回失速に関しては，本研究で報告した後縁型失速に起因するもの以外に，前縁型失速に起因するもの も報告されている（Yamanishi et al., 2007）。Yamanihsi 等が報告している失速セルの旋回速度は羽根車回転数の 半分程度であり, 本研究で報告したものよりもはるかに速い. 前縁型失速に起因する旋回失速と後縁型失速に起 因寸る旋回失速の旋回速度が大きく異なる点も興味深い。これらの失速の違いも近い将来には数值計算により解 明されることが期待される.

前報（萩谷他, 2016）では不安定特性発生前後の時間平均した内部流れを分析し，動翼の理論揚程に関して，前 縁から後縁まで領域を流れ方向に 4 分割すると，流量減少に対して後縁側（特にやや中央よりの領域）では増加 するが，最も前縁に近い領域で著しく減少し，前縁側での減少量が後縁側での増加量よりも大きくなっているこ とを報告した．また動翼 blade 2 の翼負荷に関して，チップ近傍の前縁側で失速していることを報告した．

本研究はより詳細に, 動翼チップ近傍で後縁側の負荷が比較的高いために後縁型失速が発生しており, 前縁側 の負荷が低下していることと，後縁側ではく離した流れが隣接寸る翼の迎え角を増大させていること，を明らか にした. さらに不安定特性過渡時（60.5\%流量）には前述した旋回失速が発生しており，各翼間ではく離点が負 圧面前縁に移動して前縁側で理論揚程が減少した状態（流量減少開始）とはく離点が負圧面後縁に移動して後縁 側で理論揚程が増大した状態（流量増大開始）が繰り返されているメカニズムを明らかにした．不安定特性の発 生直後（60\%流量）は前者，発生直前（61\%流量）は後者の状態に，全ての翼間が安定していると考えられる.

また，本研究で対象とした供試斜流ポンプでは不安定特性が発生するとき，動翼部で旋回失速が発生している ことを明らかにしたが，旋回失速が発生していながらも不安定特性が発生しない斜流ポンプの存在を本研究から は否定できない，さらに，本研究では吸込流量を固定した解析を実施して旋回失速の発生を確認したが，実際の ポンプでは吸込流量も微小に時間変化するため, 旋回失速の状態が安定しないことが推察される. すなわち, 旋 
回失速の旋回速度が遅いため, 旋回失速が 1 回転する間に吸込流量が変化して失速状態の翼間の数が変化したり, 全翼間が失速した状態や失速から回復した状態で安定したりして, 瞬間的には旋回失速の伝播はあるものの長時 間安定して旋回する旋回失速の観測は困難となる可能性がある. 斜流ポンプの限界設計を考える上で，旋回失速 回避の必要性は，今後の研究と設計データの蓄積により明らかにされることが期待される.

\section{6. 結 言}

比速度 $1000\left[\mathrm{~min}^{-1}, \mathrm{~m}^{3} / \mathrm{min}, \mathrm{m}\right]$ の斜流ポンプを対象とし，不安定特性の発生メカニズムを把握することを目的と して，LESにより流れ場を詳細に分析した．前報の結果から不安定特性の主要因であると考えられる動翼チップ 近傍の失速が発生したり, 理論揚程が低下したりする原因を分析するため, 過渡状態である $60.5 \%$ 流量の解析結 果に注目して, 動翼部内部流れの変化を分析した. これらの分析により, 局所的かつ非定常的な流れ場の挙動を 捉えることができ，不安定特性が発生するメカニズムを解明した．本研究から明らかとなったことは以下のとお りである.

（1）各動翼翼間流路における理論揚程と流量の時間変化を分析したところ，理論揚程が大きく流量が小さい状 態が, 羽根車の回転方向と逆向きに伝播し, 伝播速度は羽根車回転数の約 $5 \%$ あるることを明らかにした。

（2）動翼のチップ側における翼負荷，相対速度，流れ角度，および静圧の分布の時間変化を分析した．その結 果, 以下を明らかにした. ある動翼の負荷が高くなると, 動翼の後縁からはく離が発生し, はく離点は徐々 に前縁に向けて移動する.このことに伴い, 羽根車の回転方向と逆方向にある隣接翼の迎角が大きくなる, そして隣接翼の後縁側からはく離が発生し，はく離点は前縁に向けて移動する，逆に，羽根車の回転方向 にある隣接翼の流れが付着したものになると, 当該動翼の迎角が減少し, 前縁側から流れが再度付着する. しかるに,この時点において翼間の圧力勾配は大きくないため翼間流量が増大し, 失速状態から回復する.

本研究の最終的な目標は，前述のように，不安定特性を発生させることなく，斜流ポンプの限界設計を可能に することである. 本研究の成果により，例えば，動翼後縁側の負荷を後縁型失速が生じないように設計したり， 後縁型失速が発生しても隣接する動翼に対する流入角を大きくしないように設計したりすることにより, 旋回失 速の発生および不安定特性の発生を回避できる限界設計の実現可能性を示すことができた.

\section{文献}

Brooks, T. F., Pope, D. S. and Marcolini, M. A., Airfoil self-noise and prediction, NASA RP-1218 (1989).

Goto, A., The effects of tip leakage flow on part-load performance of a mixed-flow pump impeller, Journal of Turbomachinery, Vol.114 (1992), pp.383-391.

Guo, Y., Kato, C. and Yamade, Y., Basic features of the fluid dynamics simulation software FrontFlow/Blue, SEISAN KENKYU, Vol.58, No.1 (2006), pp.11-15.

萩谷功，加藤千幸，山出吉伸，長原孝英，深谷征史，LES を用いた斜流ポンプ不安定特性の原因特定， 日本機械学会論文集, Vol.82, No.834 (2016), DOI:10.1299/transjsme. 15-00533.

Hiradate, K., Shimizu, H., Nagai, Y. and Irie, K., Computational evaluation method for inception flowrate of unstable characteristic in mixed flow pumps, Journal of Fluid Science and Technology, Vol.5, No.2 (2010), pp.98-110.

加藤千幸, ラージ・エディ・シミュレーション (LES) の工学的応用,

日本ガスタービン学会誌, Vol.35, No.4 (2007), pp.213-218.

加藤千幸, 清水勇人, 岡村共由, LES による斜流ポンプ内部流れの非定常解析 (第 1 報, 解析手法), 日本機械学会論文集 B 編, Vol.68, No.670 (2002), pp.1729-1736.

Kobayashi, K., Hagiya, I., Akiniwa, H., Yoda, I. and Senba, D., Development of double suction volute pump for high efficiency, Proceedings of the ASME 2013 Fluids Engineering Division Summer Meeting, FEDSM2013-16345 (2013), Nevada, USA. 
黒川淳一，江杰，北洞貴也，斜流羽根車の入口逆流モデルと理論揚程および軸動力の予測法，

日本機械学会論文集 B 編, Vol.59, No.557 (1993), pp.143-149.

McCullough, G. B. and Gault, D. E., NACA, TN2502 (1951).

Nagahara, T., Aki, T., Tanaka, S. and Inoue, Y., Investigation of a suction bend and impeller configuration to improve the cavitation performance by use of CFD, $23^{\text {rd }}$ IAHR Symposium (2006), Yokohama, Japan.

西泰行，福富純一郎，中村俊介，翼端羽根負荷分布の異なる斜流ポンプの不安定特性に関する研究， 日本機械学会論文集 B 編, Vol.79, No.801 (2013), pp.939-952.

Pacot, O., Kato, C., Guo, Y., Yamade, Y. and Avellan, F., Large eddy simulation of the rotating stall in a pump-turbine operated in pumping mode at a part-load condition, Journal of Fluids Engineering, Vol. 138, No.11 (2017), pp.111102-1-111102-11.

Yamade,Y., Kato, C., Shimizu, H. and Nagahara, T., Large eddy simulation of internal flow of a mixed-flow pump, Proceedings of the ASME 2009 Fluids Engineering Division Summer Meeting, FEDSM2009-78416 (2009), Quebec, Canada.

Yamanishi, Y., Fukao, S., Qiao, X., Kato, C. and Tsujimoto, Y., LES simulation of backflow vortex structure at the inlet of an inducer, Journal of Fluids Engineering, Vol. 129 (2007), pp. 587-594.

\section{References}

Brooks, T. F., Pope, D. S. and Marcolini, M. A., Airfoil self-noise and prediction, NASA RP-1218 (1989).

Goto, A., The effects of tip leakage flow on part-load performance of a mixed-flow pump impeller, Journal of Turbomachinery, Vol.114 (1992), pp.383-391.

Guo, Y., Kato, C. and Yamade, Y., Basic features of the fluid dynamics simulation software FrontFlow/Blue, SEISAN KENKYU, Vol.58, No.1 (2006), pp.11-15.

Hagiya, I., Kato, C., Yamade Y., Nagahara, T. and Fukaya, M., Cause specification of performance curve instability in mixed-flow pump by LES, Transactions of the JSME (in Japanese), Vol.82, No.834 (2016), DOI:10.1299/transjsme. 15-00533.

Hiradate, K., Shimizu, H., Nagai, Y. and Irie, K., Computational evaluation method for inception flowrate of unstable characteristic in mixed flow pumps, Journal of Fluid Science and Technology, Vol.5, No.2 (2010), pp.98-110.

Kato, C., Industrial application of large eddy simulation, Journal of the Gas Turbine Society of Japan, Vol.35, No.4 (2007), pp.213-218 (in Japanese).

Kato, C., Shimizu, H. and Okamura, T., Large eddy simulation of unsteady flow in a mixed-flow pump (1st report, numerical method), Transactions of the Japan Society of Mechanical Engineers, Series B, Vol.68, No.670 (2002), pp.1729-1736 (in Japanese).

Kobayashi, K., Hagiya, I., Akiniwa, H., Yoda, I. and Senba, D., Development of double suction volute pump for high efficiency, Proceedings of the ASME 2013 Fluids Engineering Summer Meeting, FEDSM2013-16345 (2013), Nevada, USA.

Kurokawa, J., Jiang, J. and Kitahora, T., Inlet reverse flow model and prediction of theoretical head and water power of mixed-flow pumps, Transactions of the Japan Society of Mechanical Engineers, Series B, Vol.59, No.557 (1993), pp.143-149 (in Japanese).

McCullough, G. B., and Gault, D. E., NACA, TN2502 (1951).

Nagahara, T., Aki, T., Tanaka, S. and Inoue, Y., Investigation of a suction bend and impeller configuration to improve the cavitation performance by use of CFD, $23^{\text {rd }}$ IAHR Symposium (2006), Yokohama, Japan.

Nishi, Y., Fukutomi, J. and Nakamura, S., Study on instability characteristics of a mixed-flow pump of different blade loading distribution near the blade tip, Transactions of the Japan Society of Mechanical Engineers, Series B, Vol.79, No.801 (2013), pp.939-952 (in Japanese). 
Hagiya, Kato, Yamade, Fukaya and Nagahara, Transactions of the JSME (in Japanese), Vol.84, No.857 (2018)

Pacot, O., Kato, C., Guo, Y., Yamade, Y. and Avellan, F., Large eddy simulation of the rotating stall in a pump-turbine operated in pumping mode at a part-load condition, Journal of Fluids Engineering, Vol. 138, No.11 (2017), pp.111102-1-111102-11.

Yamade, Y., Kato, C., Shimizu, H. and Nagahara, T., Large eddy simulation of internal flow of a mixed-flow pump, Proceedings of the ASME 2009 Fluids Engineering Division Summer Meeting, FEDSM2009-78416 (2009), Colorado, USA.

Yamanishi, Y., Fukao, S., Qiao, X., Kato, C. and Tsujimoto, Y., LES simulation of backflow vortex structure at the inlet of an inducer, Journal of Fluids Engineering, Vol. 129 (2007), pp. 587-594. 